\title{
O propozicijskosti prislovov v slovenščini (z vidika slovanskega jezikoslovja)
}

\author{
Andreja Ž ELE \\ Univerza v Ljubljani, Filozofska fakulteta, Aškerčeva 2, \\ SI-1000Ljubljana,andreja.zele@ff.uni-lj.si
}

\begin{abstract}
Prislovi so obravnavani kot organske sestavine celostne zgradbe povedi, zato njihova načelno velika funkcijska obsežnost oz. prehodnost od propozicijskosti k nepropozicijskosti in obratno ni nič posebnega. Poleg pravih prislovov kraja in časa se med samostojne propozicijske (pomenskospodstavne) prvine uvrščajo tudi t. i. vrstni prislovi. Pomenska nujnost sestavin $\mathrm{v}$ propoziciji je povezana $\mathrm{z}$ vezljivostjo, in samo udeleženci s konkretnim (tj. denotatnim in hkrati referenčnim) pomenom so del propozicije in hkrati uvajajo vezljivost.
\end{abstract}

Since we generally consider adverbs as organic components of clause's structural integrity their broad array of use or transition from proposition to non-proposition, and vice versa, is nothing special. Apart from real adverbs of time and place, definite adverbs also rank among independent components of the proposition. They fall under semantic necessity that is tied to valency, because only those participants who have a concrete (denotative and referential) are essential components of proposition and may serve to introduce valency.

Ključne besede: propozicija, propozicijske sestavine, prislovi, upovedovanje

Key words: proposition, propositional components, adverbs, wording

0 V tej razpravi je propozicijskost omejena na jezikovno(sistemsko) pomenskost v okviru enega sporočila, ki je navadno stavčna poved. ${ }^{1}$ Propozicijo lahko razlagamo kot logični pomen stavčne povedi in kot intenčno polje povedja (Daneš 1968: 47; 1987: 56); v zvezi s propozicijo se poudarja zlasti njena »predjezikovna

${ }^{1}$ Poved izraža določeno propozicijo ali pomensko podstavo, propozicija pa prikazuje določeno dejstvo (SS 2000: 733). 
pomenska zgradba«, ki propozicijo uvršča na »mišljenjsko ravnino«, ta pa je po eni strani prek inteligence povezana $\mathrm{z}$ realnostjo, po drugi strani pa prek jezikovnih pomenov vodi v upovedenje oz. ubeseditev (Šoltys 1986: 1-2). V smeri k upovedovanju to propozicijo kot pomensko podstavo oz. bazo sestavlja množica bazičnih in kompleksnih pomenov (vezanih na vsebino entitet) z vzpostavljenimi pomenskimi razmerji (Kořenský 1984: 16). Z vidika zaključenega sporočila lahko govorimo o istopropozicijskosti in o (širši) medsporočilni neistopropozicijskosti sestavin/enot nasproti nepropozicijskim sestavinam.

Prislovi so zaradi t. i. vektorskih funkcij obravnavani kot organske sestavine celostne zgradbe povedi oz. sporočila, zato njihova načelno velika funkcijska obsežnost oz. prehodnost od propozicijskosti k nepropozicijskosti in obratno ni nič posebnega (Pen'kovskij 2004: 291-292).

Poleg pravih prislovov kraja in časa, ki so že po organskosti jezika samostojne propozicijske oz. bazične pomenske sestavine, se glede na svojo samostalniško motivacijo med samostojne propozicijske (pomenskospodstavne) prvine uvrščajo tudi t. i. vrstni prislovi ${ }^{2}$, ki glede na pomenske lastnosti motivirajočega samostalnika vrstno opredeljujejo glagolsko dejanje/dogodek. Prislovi skladenjskopomensko natančneje določajo glagol glede na prostor, čas (ki sta takorekoč bivanjsko samoumevna), sredstvo (snov), spremstvo, vzrok, ${ }^{3}$ ozir ali izid; ${ }^{4}$ te izrazljive/zunanje okoliščine so navadno skladenjskopomensko vezljive in zato hkrati tudi propozicijske, ${ }^{5}$ npr. laboratorijsko pregledati, enkrattedensko poročati, računalniško obdelati, parno drsati, zakonsko zagotoviti, slovnično popraviti, klinično živeti/umreti, metodološko dokazati, krvno maščevati ipd. nasproti prislovom v vlogi lastnostnih modifikatorjev tipa temeljito/dobro pregledati, redno poročati ipd. Navajani primeri samo še potrjujejo, da so vrstni prislovi neke vrste sporočevanjski zgoščevalniki (Sgall 1968: 167) znotraj iste propozicije oz. iste stavčne povedi; imenujejo jih tudi »subpropozicije« (Adamec 1978: 278), ker se v stavčni povedi z vrstnim prislovom navadno ubesedujejo zložene propozicije - na izrazni ravni pa se stavčne ubeseditve zložene propozicije ne razlikujejo od stavkov iz navadne/nezložene propozicije. Propozicijskosti vrstnih pridevnikov v okviru stavka je možno dodati vzporedno propozicijskost na besednozvezni ravni. ${ }^{6}$

\footnotetext{
${ }^{2}$ Tovrstne prislove imenujemo tudi generični prislovi. Po Švedovi (1968: 69) vrstni prislov izraža konkretnejšo okoliščino nasproti abstraktnejšemu predponskemu obrazilu.

${ }^{3}$ Jezikovna vzročnost je odraz fizične/materialne vzročnosti v mišljenju oz. zavesti.

${ }^{4}$ Pri nas je bilo še najbolj eksplicitno dosedaj na pojav, tipologijo in vloge vrstnih prislovov opozorjeno v monografiji Slovensko leksikalno pomenoslovje (A. Vidovič Muha 2000: 76-77). V češčini, kot enem izmed skladenjskopomensko bližjih jezikov, je na vlogo prislovov iz konkretnega samostalniškega pomena med drugimi večkrat opozarjal J. Kořenský (1984: 65).

${ }^{5}$ P. Piper (22001: 45) tako npr. ločuje nepropozicijsko notranjo kavzalnost, npr. oženiti se iz ljubavi, od zunanje kavzalnosti, npr. umreti od naboja, ki je propozicijska.

${ }^{6}$ Tu je treba omeniti bistveno jezikovnosistemsko opozorilo A. Vidovič Muha (2009: 253), da je potrebno razmisliti o pritegnitvi v propozicijo še prave (izsamostalniške) vrstne pridevnike, ki s samostalniškim jedrom tvorijo stalno besedno zvezo oz. en leksem.
} 
V primeru vrstnega prislova $\mathrm{v}$ stavčni povedi se namreč združujeta besedna (stavčna) in morfemska (besedotvorna) sintagma. Prostor in sredstvo kot konkretni entiteti in zato tudi samostojni propozicijski sestavini se lahko ubesedujeta implicitno (kot morfemski del glagola, npr. stražiti 'biti na straži', ponočevati 'biti (nekje) ponoči', krampati 'delati s krampom', moževati 'gibati se med možmi') ali eksplicitno kot /predložna/ imenska zveza (v paru, $v$ ambulanti, z injekcijo) ali prislov (parno, ambulantno, injekcijsko). V naštetih primerih gre za različno stopnjo diateznosti med spoznavanjsko/logično propozicijo in ubeseditvijo.

Povezovanje propozicijskosti stavčnih povedi s propozicijskostjo besedotvornih (morfemskih) sintagem kot so večbesedni leksemi tipa stenska ura, prenosnik (< prenosni aparat) pa samo še utrjuje spoznanje, da je jezik nedeljiva sistemska celota (Vidovič Muha 2009: 253).

\section{Prislovi kot samostojne sestavine propozicije in prislovi kot (obvezne) sestavine upovedovanja}

In kateri prislovi, poleg prostorskih in časovnih, so še potencialne samostojne sestavine propozicije? Še vsi drugi, ki uvajajo načinovna in vzročna razmerja s konkretnimi entitetami, tj. prislovi načina, prislovi sredstva/spremstva, vzroka, ozira. ${ }^{7}$ Vzrok in ozir izražata neposredno razmerje s predmetom, kajti tudi pri oziru in vzroku je bistvena sestavina 'prostorskost' (Vinogradov 1947: 377, 379). Možno propozicijskost prislovov izražajo tudi jezikoslovna poimenovanja kot prislovno določilo sredstva/orodja. ${ }^{8}$

Vrstni prislovi so navadno s stališča matične propozicije vedno tudi neke vrste posredne prostorske opredelitve, tj. prostor je določen prek konkretne predmetnosti in vsebin, ta prostorska opredelitev pa se veže na konkretno položajskost vršilca oz. nosilca določenega dejanja/dogajanja/procesa $;{ }^{9}$ prehod iz konkretnih vsebin tudi na konkretna razmerja je lepo izražen s primeri tipa peljati se z avtom (češ.: jet avtem). Glede na povedano lahko pri vrstnih prislovih kot potencialnih propozicijskih oz. logično-pomenskih sestavinah zelo upravičeno govorimo o globinskih sklonih po Fillmoru $(1965,1968)$. Dejstvo

\footnotetext{
${ }^{7}$ Entiteta v tem primeru označuje materialno pojavnost, ki je vezana na obstoj v prostoru in času.

${ }^{8} \mathrm{Z}$ vidika skladenjskopomenske sorodnosti jezikov je opozorjeno tako v slovenskem kot češkem jezikoslovju (Vidovič Muha 1988: 63-64, 69; MČ 3 1987: 116; Daneš 1987: 49, 55, 93). Vidovič Muha (1988: 69): »Med prislovna določila načina spada tudi prislovno določilo sredstva in orodja (glagolskega) dejanja /.../; dokaz, da gre dejansko za prislovno določilo in ne za orodniški predmet je vsaj v hipotetični pretvorbi predložnega prislovnodoločilnega samostalnika v izprislovno določilo: elektrošok $<$ to, da šokira z elektriko > električno šokira ipd.«

${ }^{9}$ Pogoj za propopozicijskost oz. pomenskosestavinskost prvine je njena primarna prostorskost - lahko govorimo o prostorsko motiviranih jezikovnih metaforah (Piper ${ }^{2} 2001$ : 147).
} 
tudi je, da so vršilec, dejanje, prostor in sredstvo v najtesnejši povezavi in soobstoju na ravni logične/spoznavne oz. propozicijske zgradbe jezika, ki je hkrati tudi logična/spoznavanjska baza jezika; zlasti vsebino razmerij med naštetimi bistvenimi entitetami pa lahko izražajo prislovi (Grepl 1987: 41).

Nasproti izpridevniškim lastnostnim prislovom, ki lastnostno opredeljujejo (modificirajo) glagolsko dejanje/dogajanje/stanje, so vrstni oz. samostalniško motivirani prislovi ravno zaradi svoje konkretne prostorskosti samostojne sestavine propozicije stavčne povedi. ${ }^{10}$ Ravno z večjo konkretizacijo se z vrstnimi prislovi v sporočilu jasneje ločuje vsebina od dodane sporočanjske subjektivnosti oz. avtorskosti, ki pa se propoziciji dodaja šele v procesu upovedovanja. Naklonskost (z izraženim sporočevalčevim doživljajskim in siceršnjim razmernim odnosom) je namreč tudi obvezni sestavni del upovedovanja in zato tudi konstitutivni (bistveni) del povedja in nato povedi. ${ }^{11}$ In če je v procesu upovedovanja z jezikoslovnega vidika koristno jasno stopenjsko ločevanje propozicije (tj. pomenske podstave s pomenskimi sestavinami) od končne izražene povedi, je v končnem upovedenem sporočilu seveda to neločjivo združeno. Torej predstavitev oz. ugotovitev, katere jezikovne (denotatne) prvine pomensko samostojno funkcionirajo že na propozicijski stopnji, ni razlog za strah, da bi prišlo do »nasilnega razmejevanje naklonskih pomenskih sestavin od propozicijskih« (Kunst Gnamuš 1981: 55), in lahko se samo še potrjuje, da »V sleherni povedi sočasno izražamo predmetno vsebino ter hkrati naše razmerje do nje in naslovnika /.../ da je naklonska sestavina najpomembnejša in najbolj površinska pomenska plast. /.../«. Dejansko stanje, izraženo s propozicijo, je torej »le leča, skozi katero se lomijo žarki sporočevalčevega videnja«.

1.1 V okviru prislovov je ključno tudi osnovno vprašanje adverbizacije določenih predvsem predložnih imenskih zvez, kjer se predlog abstrahira v prislovno razmerje, pomenska motivacija pa je v samostalniku, npr. doslej, opolnoči, dnevno, tedensko, mesečno, predvčerajšnjim ipd. Z vidika vezljivostne hierarhizacije povedkovega glagola in tudi s stališča zgradbene organizacije stavčne povedi je pomenljivo, da povedkovi glagoli prvenstveno težijo k adverbizaciji (predložnih) imenskih zvez v vlogi prislovnih določil načina (Knappová 1973: 152; Rusínová 1972: 182-185). Poenobesedenje oz. leksikalizacija predloga pa

\footnotetext{
${ }^{10} \mathrm{~V}$ okviru iste pomenske podstave oz. propozicije stavčne povedi lahko ločujemo prislove kot nesamostojne ali samostojne pomenskopodstavne sestavine nasproti drugopozicijskim sestavinam.

${ }^{11}$ O. Kunst Gnamuš (1987/88: 8-16) ugotavlja, da upovedovalna teorija izgublja jasnost in preglednost zaradi nejasnih prehodov med propozicijsko in naklonsko pomensko plastjo. To pa po njenem mnenju izhaja iz tega, ker je delitev človeka na spoznavno bitje na eni strani in na pragmatično bitje na drugi strani nasilna. Po vsem tem avtorica prihaja do sklepa, da bi bilo vredno poskusiti propozicijsko pomensko sestavino razčleniti na dve plasti - na a) plast doživljajsko nepredelane predstave o zunanji predmetnosti - Pd in na b) plast miselnih in doživljajskih razmerij/pričakovanj - Pr/p. Zagotovo sta v proces upovedovanja nujno vključeni obe omenjani plasti, od namenskosti sporočanega pa je potem odvisno, kaj je izrazljivo obvezno in kaj neobvezno oz. izpustljivo.
} 
je sprejemljivejša in hitrejša pri abstraktnih imenih, npr. $z$ veseljem $>$ veselo, tako še brezskrbno, zmerno, ponoči, vsakodnevno ipd.

\section{Merila za vključevanje prislovov med samostojne propozicijske sestavine}

Novejše slovenske jezikoslovne študije (prim. Slovensko leksikalno pomenoslovje /SLP/ A. Vidovič Muha 2000) v okviru tipologije vrstnih prislovov (s samostalnikom v podstavi) eksplicitno odpirajo vprašanje propozicije globinskega udeleženca, pri lastnostnih (izglagolskih) prislovih pa je opozorjeno na pojav cele propozicije v drugi propoziciji.

Meja med propozicijskostjo in nepropozicijskostjo, med vsebino entitete in lastnostjo entitete, in posledično prehodnost med vezljivostjo in družljivostjo je še najbolj razložljiva s t. i. vrstnimi (samostalniško motiviranimi) prislovi. Vrstni prislovi (SLP: 76-77) so pretežno, glede na samostalniški izvor, izudeleženska obpovedkova prislovna določila - pretvorbno pa vključujejo tako delovalnike (računalniško, radijsko, medijsko) kot okoliščine (ambulantno, tovarniško, laboratorijsko), npr. To obdeluje samo strojno, Že večkrat so ga samo ambulantno zdravili, Dela honorarno, Politično in kulturno deluje ipd.

\subsection{Poudarjen pomensko-pretvorbni vidik}

Vrstni prislovi zaradi pomensko-pretvorbnih zmožnosti v prostostavčno poved vnašajo tudi paradigemska razmerja - sporočilo se popolno uresniči še z dodanim paradigemskim podsistemom /pre/tvorb. ${ }^{12}$ Propozicijskost je vezana na obstoj, obstoj pa na prostor, s čimer lahko utemeljujemo propozicijskost določenih besed v sporočilu - npr. parno je propozicijski prislov, ker ga lahko tudi razložimo z dodatnim glagolom s polnopomenskim glagolom biti v pomenu 'nahajati se', ki je samo istopropozicijska konkretizacija razmerij, npr. On parno drsa ↔ 'On drsa. Je (z nekom) v paru', nasproti nepropozicijskemu posamezno, ki se razvezuje s pomočjo pomožnega biti + kot, npr. On drsa posamezno $\leftrightarrow$ 'On drsa. Je kot posameznik', kjer je v ospredju podobnost kot stanjska lastnost. Ravno tovrstne razvezave omogočajo, da prislove označimo tudi kot 'vrinjeni globinski povedki', 'vložene povedi' ali kot 'stavčni prislovi' (J. Orešnik 1994: 125; 1996: 257). V zvezah tipa skupinsko delovati, pa je prislov skupinsko lahko propozicijski v smislu Delujejo v skupini ali nepropozicijski/ podobnostni v smislu Delujejo kot skupina / kot v skupini, kjer je spet zgolj

12 Po J. Kořenském (1974: 244) sta v primeru vrstnih prislovov uresničeni obe stopnji realizacije propozicije - 1) leksikalna in skladenjska in 2) besedotvorna in morfološkoskladenjska. 
podobnost ali Politično deluje ( $<$ 'Deluje v politiki'13 (propozicijsko) nasproti Deluje kot politik (podobnost kot lastnostna oznaka). V razmerju med strokovno oceniti (< 'oceniti glede na stroko') nasproti strokovnjaško oceniti $(<$ 'oceniti kot strokovnjak') je propozicijsko samostojni prislov strokovno. V povedi To se izključuje avtomatsko (< To se izključuje z avtomatom / na avtomatu - To izključuje avtomat) se na primeru prislova avtomatsko potrjuje, da je vrstni prislov skladenjskobesedotvorna sinteza sredstva dejanja (Sd), mesta dejanja $(\mathrm{Md})$ in vršilca dejanja $(\mathrm{Vd})$. Večkrat in v različnih obdobjih je bila je že bila potrjena pretvorbna naveza vršilec/povzročitelj - sredstvo - orodje - vzrok, ki jo pogosto pretvorbno-izrazno zgošča vrstni prislov (Mrázek 1976: 90), npr. Dvigalo avtomatsko oz. računalniško dostavlja posamezne izdelke, Ljudje ročno ali strojno obirajo pridelek.

2.1.1 Propozicijskost vrstnih pridevnikov se lahko potrjuje tudi s tem, da npr. propozicijski ozirni (načinovni) prislov ne more stati ob kakovostni nestanjski pridevniški besedi, npr. lep v obraz > *obrazno lep, dolg v roke > *ročnodolg (Vidovič Muha 1988: 108), možno pa je mrežastokril (< 'krila kot mrežo' nasproti *krilnomrežast < 'mrežast v krila' ipd.). Za propozicijske vrstne prislove tudi velja, da imajo v skladenjski podstavi predložno samostalniško zvezo ob polnopomenskem biti 'nahajati se', npr. klinično mrtev / živ ('glede na kliniko / na klinično stanje, pregled').

S pomensko-pretvorbnega vidika, in zato posredno, propozicijsko pomembnost prislovov dokazujejo in potrjujejo motivirani glagoli tipa deskati, grabiti, moževati, naoljiti, planinariti, pomokati, ponočevati, sankati, sončiti, vedriti ipd.; propozicijskost prislovnega določila sredstva pa se potrjuje tudi z možnostjo pretvorbe $\mathrm{v}$ odvisnik s polnopomenskima biti ali imeti $\mathrm{v}$ sankati se $z$ lopato / na lopati < 'sankati se, tako da ima lopato /da je na lopati', kositi s srpom ipd.

Sinkretizem oz. možno združevanje udeleženskih vlog v primerih streljati iz puške s slepim nabojem se razlaga z možnostjo pretvorbe prislovnega določila sredstva v odvisnik z biti v pomenu 'nahajati se': streljati iz puške, tako da je $v$ njej slepi naboj (o tem tudi Běličová 1982: 141; 1996: 173).

$\mathrm{S}$ tvorbenega vidika na propozicijskost vrstnih pridevnikov opozarjajo tudi dvonaglasne tvorjenke tipa literárnozgodovínski, céstnoprométni, denárnogospodárski, kjer je naglašen tudi podstavni vrstni pridevnik.

\subsection{Poudarjen funkcijski vidik.}

Po naši slovnični tradiciji (SS 2000: 492) nujno potrebne sestavine propozicije tvorijo propozicijsko jedro, določa pa jih glagolska vezljivost. Pomenska nujnost sestavin $\mathrm{v}$ pomenski podstavi oz. propoziciji je torej povezana $\mathrm{z}$ vezlji-

${ }^{13}$ Leksem politika je po Piperju (22001: 146) v primerih kot Deluje v politiki, Iti v politiko ipd. lahko v vlogi prostorsko motivirane metafore. 
vostjo, in samo udeleženci s konkretnim (tj. denotatnim in hkrati referenčnim) pomenom, ${ }^{14}$ ki so neposredno ali pretvorbno vključeni v stavčno skladnjo, lahko uvajajo vezljivost. ${ }^{15}$

Konkretni jezikovni odraz propozicijskosti določenih vsebin na vseh ravninah jezika je torej vezljivost. Vrstni prislovi tudi pretvorbno-stavčno (glede na predpovedkov položaj $\mathrm{v}$ stavku) potrdijo vsebinsko vezljivost $\mathrm{v}$ okviru prisojevalnega razmerja, kar sicer izražajo tudi prislovnodoločilno rabljene predložne zveze. Da lahko govorimo o neke vrste vzporedni vsebinski vezljivosti v okviru prisojevalnega razmerja potrjujejo primeri Sedijo v plaščih $(\mathrm{Pd} \cap \mathrm{Md}$, poudarek je na mestu dejanja /Md/) ali Teče v nogavicah $(\mathrm{Pd} \cap \mathrm{Md}$, poudarek je na predmetu dejanja /Pd/) (prim. Kř́̌žková 1968: 105, 107); tovrstno spremljajočo vsebinsko vezljivost $\mathrm{v}$ prisojevalnem razmerju bi jezikoslovno označili kot primik ali celo kot šibko vezavo (»slabá rekce«/Adamec 1968: 113/) ali kot kompleksno vezavo zaradi implicirane sporočilnosti (»kompleksní vazba« /Jelínek 1968, 390/). Sem spadajo tudi primeri, ki vključujejo sredstvo (Sd), npr. Rana je od noža (prevedeno iz češčine Rána je nožem, Kořenský 1984, 83); podobni primeri za snov/sredstvo so še To je od barve, za vzrok pa To je zaradi barve ipd. V zvezi z vrstnimi prislovi se v ruskem jezikoslovju govori tudi o 'kategoriji objektivne modalnosti v okviru predikativnosti' (Švedova 1968: 69).

Funkcijskost propozicijskih prislovov označujejo v slovanskem jezikoslovju poimenovanja kot 'kompleksna propozicija' (Grepl/Karlík 1998: 42), 'virtualna propozicijskost' v povezavi s virtualno vezljivostjo (Pen'kovskij 2004: 290). V češkem jezikoslovju (P. Sgall, E. Hajičova, J. Panevova 1986b: 143) zasledimo tudi oznako 'dvojna odvisnost' (double dependency), ki skuša nakazati vzporedno vezljivost s prisojevalnim razmerjem.

O. I. Moskal'skaja (1973: 40) se med možnostima, da 'povedek označuje razmerje med osebkom in prislovnim določilom načina' ali da 'povedek skupaj s prislovnim določilom načina natančneje določa osebek' smiselno odloči za slednjo, ki jo označi kot 'povedkovo-okoliščinska opredelitev povedi' (processual'no-obstojatel'stvennye determinijuščie predloženija). Pretvorbeno združevanje dejanja z načinom potrjujejo tudi zgledi kot Pritlično se je namestil $<$ On se je namestil, tako da je v pritličju, podobno še pri On deluje podtalno ipd. Vsekakor pa je smiselna uporaba vrstnih prislovov (npr. prostorskih, sredstvenih) odvisna od povedkove vezljivosti.

S stališča prislovnodoločilno rabljenih sredstev pa je smiselna propozicijska sestavina prislovno določilo sredstva (Grepl 1987: 116; Vidovič Muha 1988: 69): ${ }^{16}$ obstoj propozicijskih prislovnih določil sredstva potrjuje tudi njihov stavč-

${ }^{14}$ O tem Daneš (1987: 55), ki udeležence deli na tiste, ki imajo denotativni, referenčni in konkretni pomen in na druge, ki so nedenotativni, nerefenčni in abstraktni.

${ }^{15}$ Nujnost enoumne sporočilnosti povedi kot glavnega merila za /ne/obveznost stavčnih členov zagovarja P. Sgall (1986a: 65-66, 122).

${ }^{16}$ Po češki slovnici (Grepl, Karlík 1998: 253) gre za »sredstvo v širokem smislu« ('prostředek v širokém smyslu'). 
ni soobstoj z nepropozicijskimi lastnostnimi prislovi v primerih kot Obdeloval je z dletom hitro in krožno.

\subsection{Pretvorbno-funkcijski vidik}

S pretvorbno-funkcijskega vidika bi lahko po Ju. D. Apresjanu samostalniško motivirane vrstne prislove vključili v 'motivirano obvezno vsebinsko vezljivost', nasproti lastnostnim izpridevniškim prislovom, ki jih funkcijsko opredeljuje kot 'nemotivirano obvezno vsebinsko vezljivost', in slednja zlasti vezljivostne posebnosti glagolov samo poudari, npr. enovezljivost zameji samo na vršilskost, npr. dolgo trajati, lepo se obnašati. ${ }^{17}$ Samo z vršilcem/nosilcem dejanja se lahko upovedujejo tudi lastnostni izglagolski prislovi, npr. sede kuhati, kleče prositi ipd. Slednji so že zaradi izglagolske motivacije vzporedne propozicije.

2.3.1 Tudi povedkovi udeleženci se delijo na povedkove delovalnike (s konkretnim/denotatnim pomenom - po Ju. D. Apresjanu je to 'nemotivirana obvezna vsebinska vezljivost' (21995: 165), npr. hekersko delovati, izvidniško se gibati ('delovati kot heker', 'gibati se kot izvidnik' nasproti propozicijski rabi honorarno delovati / delovati za honorar), in povedkove okoliščine (z abstraktnim/ nedenotatnim pomenom), izražene z izpridevniškimi prislovi, npr. dobro kuhati, lepo slikati ipd. ${ }^{18}$

2.3.2 Vezljivostno neobvezne ali družljivostne sestavine propozicije so lahko v okviru besedila že potencialne sekundarne propozicijske sestavine - vse je odvisno od pomena glagola v povedju; pri Zdravi se ambulantno je ambulantno lahko primarna ali sekundarna propozicijska sestavina, odvisno kateri skladenjski pomen glagola zdraviti je upoštevan, npr. ali Zdravi se in zdaj je $v$ ambulanti ali Zdravi se $v$ ambulanti in ne $v$ bolnici.

\footnotetext{
${ }^{17}$ Apresjanova 'nemotiviranost' je tu z vidika glagola mišljena kot pomenskoskladenjska neusmerjenost (nasproti glagolski pomenskoskladenjski usmerjenosti, ki jo enačimo z glagolsko vezljivostjo). Sicer pa pomensko- in strukturnoskladenjsko vlogo prislovn/ (o)zveznih dopolnil ruska skladenjska teorija označuje kot 'določnostno odvisnost' v nasprotju z 'udeležensko odvisnostjo', gl. Ju. D. Apresjan (21995: 51, 130).

Češka skladenjska teorija, gl. Mluvnice češtiny - Skladba (1987: 18, 38, 192, 254), takšne primere označuje kot »syntagmata rozvitá«. Izpridevniška prislovna določila načina so opredeljena kot skladenjsko obvezna dopolnila (t. i. 'skladenjska relevanca', ki oblikuje 'obrobni/stranski tip (okrajový typ) stavčnega vzorca') predvsem v izpeljanih stavčnih zgradbah v okviru sekundarne diateze - „adverbiální výrazy se stávají obligatorním komponentem derivované struktury«, v nasprotju s »syntagmatu valenční«.

${ }^{18}$ V. S. Hrakovskij (1985: 5-8) ima 'konstrukcije s povedkovimi delovalniki' (»konstrukcii s predikatnymi aktantami«), izpridevniški prislovi pa so predstavljeni tudi kot 'konstrukcije s širšim obsegom' oz. kot 'konstrukcije s povedkovo okoliščino' (»konstrukcii s predikatnym sirkonstantom «).
} 
2.3.3 Nepropozicijske oz. nesamostojne propozicijske sestavine izražajo podobnost oz. lastnost razmerja. Tudi nepropozicijska samostalniško motivirana prislovna dopolnila z impliciranim udeležencem ( $v$ prvotni povedkovodoločilni vlogi) vzpostavijo skladenjskopomensko navezavo z glagolom, npr. Včasih je tekmovalno sтис̌al, danes pa smuča le ljubiteljsko, ${ }^{19}$ nasproti propozicijskim prislovnim določilom kot npr. To se upravlja daljinsko ali ročno. ${ }^{20}$ Uvajanje medpropozicijskih prislovnih dopolnil tipa tekmovalno je hkrati tudi prehod v besedilno skladnjo. ${ }^{21}$

\section{Merila pomenskosti udeležencev in glagolov pri vezljivih prislovnih določilih načina}

Za propozicijskost in hkrati tudi vezljivost prislovnega določila načina je $\mathrm{v}$ nadaljevanju treba eksplicitno poudariti nekaj izhodiščnih meril pomenskosti udeležencev in glagolov.

V okviru udeležencev, ki izražajo sredstvo, orodje ali način - 's čim ali kako nekaj ustvarjati ali upravljati' je pogoj za propozicijskost in posledično vezljivost, kot že rečeno, tudi konkretna (denotatna) pomenskost udeležencev, ${ }^{22}$ in tudi (bolj) konkretna pomenskost glagolov - vsak pomenski odmik glagolov v pomensko posplošenost namreč hkrati pomeni spremembo iz predmetne

${ }^{19}$ Včasih je tekmovalno smučal ali Včasih je smučal kot tekmovalec lahko razvežemo v Včasih je smučal. Bil je tekmovalec in v slednji povedi je tekmovalec v vlogi t. i. povedkovega aktanta oz. povedkovega udeleženca, ki ga češka slovnica poimenuje tudi »kopredikátový komplement« (Grepl/Karlík 1998: 255), uvaja pa povedkovodoločilno vezljivost. Vsekakor primer potrjuje besedilnost vezljivosti.

${ }^{20}$ Meja med neudeleženskimi izpridevniškimi prislovi in izudeleženskimi (izsamostalniškimi) prislovnimi zvezami ali pretvorbami je razlagalno nakazana v slovarskih razlagah Slovarja slovenskega knjižnega jezika (SSKJ), ta so npr. pri slovarski iztočnici delati, neudeleženski izpridevniški prislovi lahko vključeni v pomenske razlage: 'kazati do česa določen odnos, ki se izraža zlasti v dejanjih' grdo/prav delati z knjigami, 'izpolnjevati, opravljati kako nalogo' uspešno/pridno/veselo delati < delati in biti uspešen/priden/ vesel, pri iztočnici gledati - 's pogledom izražati kaj' grdo/prijazno/lepo gledati, 'imeti določen odnos do česa' čisto drugače gledati na svet, pri jemati - 'imeti določen odnos do česa' jemati kaj resno, tragično, pri misliti 'imeti pozitiven ali negativen odnos do koga, česa' Dobro, slabo misli o meni.) Izudeleženski prislovi oz. prislovne zveze pa so označeni s pomenskimi razlagami 'zavestno uporabljati telesno in duševno energijo za pridobivanje dobrin' umsko/ročno delati < delati z umom / delati na roko, 'opravljati delo na določenem področju', npr. kulturno/politično delati < delati v kulturi/politiki.

${ }^{21}$ Vse to potrjuje, da mora vsak skladenjski slovar biti vezljivostno-kolokacijski slovar le tako lahko zajame čimbolj pristno živo rabo, ki se navezuje tudi na nadpovedno oz. besedilno skladnjo.

${ }^{22} \mathrm{Na}$ konkretno, tj. na razmerno-prostorsko, povezanost orodja in načina $\mathrm{v}$ različnih jezikoslovnih kontekstih opozarja tudi sodobnejše rusko jezikoslovje (Muravenko 1998: 77) s pripombami kot: orodje je lahko sestavina načina dejanja oziroma tudi povedje $z$ vključenim načinom dejanja ima vezljivo orodje dejanja. 
(prave udeleženske) vezljivosti v prislovnodoločilno vezljivost oz. družljivost, in vsak pomenski odmik glagolov v oslabljeni pomen hkrati pomeni odmik $\mathrm{v}$ povedkovo/določilno/ kvazivezljivost, npr. delati z dletom/krampom, delati strojno (kako? = zaradi velike splošnopomenskosti glagola je to lahko povedkova oz. povedkovodoločilna vezljivost) nasproti rezljati z dletom / strojno / laboratorijsko / v laboratoriju $(\mathrm{s} \mathrm{čim} ?=\mathrm{z}$ dletom $=$ predmetna vezljivost, kako? $=$ strojno $=$ prislovnodoločilna vezljivost, $\mathrm{kje} ?=$ prislovnodoločilna vezljivost $) ;{ }^{23}$ tudi in še zlasti z vidika udeležencev je nujni pogoj za vezljivost konkretna (predmetna ali vsebinska) pomenskost udeležencev, npr. delati z dletom, delati $z$ besedilom, ${ }^{24}$ nasproti nevezljivi abstraktni pomenskosti udeležencev (navadno so to lastnostne okoliščine), npr. delati z veseljem / veselo. ${ }^{25}$

3.1 $\mathrm{Z}$ vidika udeleženskosti in vezljivosti so posebnost t. i. sestavljeni udeleženci z možnostjo hkratnega nastopanja $\mathrm{v}$ več udeleženskih vlogah, ki hkrati odpirajo propozicijska mesta - vlogi vršilec/nosilec dejanja in način dejanja - najtipičnejši primeri so človek - delujoči del telesa, npr. Tone to dela ročno / pametno / z glavo, Toneta boli trebuh / Toneta boli v trebuhu, ki omogočajo soobstoj osebkove/predmetne vezljivosti in prislovnodoločilne vezljivosti (krajevne ali načinovne). Nasprotje sestavljenim udeležencem, ki odpirajo nova skladenjskopomenska mesta oz. udeleženske vloge, je udeleženec, ki v eni/obstoječi udeleženski vlogi združuje več možnih udeleženskih vlog, npr. Avtobus nas je pripeljal na cilj, osebek avtobus v tem primeru združuje udeleženske vloge vršilca dejanja, sredstva dejanja in mesta dejanja, tj. 'avtobus

${ }^{23} \mathrm{~V}$ zadnjih desetletjih je pri nas na pričakovano odločilno pomensko soodvisnost povedkovo-udeleženskega razmerja tako s skladenjskobesedotvornega kot s skladenjskopomenskega vidika opozorila A. Vidovič Muha. V Slovenskem skladenjskem besedotvorju (SSB 1988: 63-64) je poveden komentar: »/.../ Zlasti če je samostalnik pojmovni, precej teh /podstavnih/glagolov sili v primično razmerje: silobran < to, da se brani s silo / v sili /.../; v teh primerih seveda nimamo opravka z orodniško vezavo. Morda so še nekoliko dvoumni primeri kot strojepis < to, da pišejo s strojem, kjer bi orodniški predmet lahko zamenjal prislov strojno.«

${ }^{24}$ Tako v slovenskem kot češkem jezikoslovju se v tovrstnih primerih govori o prislovnem določilu orodja/sredstva. V slovenskem jezikoslovju o "prislovnem določilu sredstva in orodja« (Toporišič 1982: 77-78; ${ }^{4} 2000$ : 623; Vidovič Muha 1988: 69; Sgall 1986: 128-129: »určení doprovodu, vyjadřované primárně předložkovým pádem«; »určení nástroje«, určení látky/materiálu«, »určení prostředku transportu«, Grepl. Karlík 1998: 253-254, 283-284). V Mluvnice češtiny (MČ 3 1987: 50-51, 61-62, »způsoby vyjádření nástroje činnosti«) se možna vezljivost prislovnih določil načina potrjuje z ugotovitvijo, da povedkova vezljivost lahko zahteva tudi prislovna določila načina, ki so besednovrstno največkrat predložne samostalniške zveze.

25 Tudi po češki jezikoslovni tradiciji, npr. po M. Greplu in P. Karlíku idr. (v Skladbi češtiny, 1998), lahko na eni strani govorimo o valenčnih prislovih (»adverbiální (příslovečný) komplement«, 252), po drugi strani pa v zvezi s prislovnimi (izpridevniškimi) dopolnili lahko govorimo o nevezljivih dopolnjevalnih lastnostnih okoliščinah oz. o lastnostnih modifikatorjih, ki glagolske pomene dopolnjujejo oz. pomensko določajo navznoter, in zato ne delujejo v smislu glagolske intence oz. valence navzven. 
je bil hkrati naš prevoznik, naše sredstvo prevoza in mesto prevoza'. To so tipični primeri diateze.

T. i. sestavljeni udeleženci so zaradi dvoje udeleženske vloge tudi dvoja vezljivostna posebnost, ker navadno zaradi njihove visoke stopnje vršilskosti en sestavni del udeleženca prevzame vodilno udeležensko vlogo vršilca/nosilca dejanja, drugi sestavni del udeleženca pa je v vlogi vezljive okoliščine načina dejanja, npr. Božal ga je z očmi (kako? => z očmi) - v teh primerih možna pretvorba Njegove oči so ga božale samo še potrjuje del telesa oz. organ kot delujoči del osebka; sicer delujoči osebkov del v orodniku lahko obravnavamo tudi kot kvazivezljivost delnega (telesnega) delovalnika, npr. Mahal je z roko (kako? = kvazivezljivost) se tako pomensko in slovnično razlikuje od Maha $z$ robcem (s čim? = prava vezljivost).

Neke vrste prehod med neudeleženskimi in /iz/udeleženskimi obpovedkovimi dopolnili so primeri, kjer vsebinski udeleženec pomenskoskladenjsko natančneje lastnostno oz. načinovno opredeljuje povedkov glagol, npr. iz športa On plava metuljčka/žabico ('kot metulček / kot žabica'), Drsa parno/ v paru / Drsa s kom v paru (nasproti že lastnostno rabljenim drsati posamezno / kot posameznik).

3.2 Najširše in najobširnejše možnosti uporabe vezljivih načinovnih določil imajo splošnopomensko in oslabljenopomensko rabljeni glagolski pomeni. To tudi sicer sovpada s splošnejšo jezikoslovno ugotovitvijo, da je vezljivost načina lastna širšemu obsegu glagolov in da tudi sicer ni praktično noben način (popolnoma) neodvisen od glagola.

Konkretizirani glagolski pomen v povedku omogoča zlasti predmetno vezljivost, medtem ko raba posplošenega pomena predmetno /pretežno orodniško/ vezljivost (orodja ali sredstva) spremeni v prislovnodoločilno vezljivost načina (uporabe tega orodja ali sredstva), npr. obžagati z motorko : obrezati z motorno žago : oklestiti z žago / s sekiro $(\mathrm{s}$ čim? = predmetna vezljivost $)>$ obdelati z žago / s sekiro $($ kako? $=$ prislovnodoločilna vezljivost $)>$ obdelati z žago / s sekiro (je v smislu pretvorb obžagati/obsekati lahko tudi povedkovodoločilna vezljivost ob pomensko oslabljeni rabi glagola). ${ }^{26}$ Torej vsaka možna besedotvorna vključitev udeleženca v glagolski pomen tipa obžagati/obsekati hkrati vzvratno kaže na možno oslabljeno rabo glagola obdelati, in hkrati na njegovo splošno oz. širokopomensko rabo, ki dopušča vezljivost različnih orodij in sredstev v smislu načina ravnanja, ker ne zamejuje uporabe orodja in sredstva na samo določeno orodje/sredstvo v konkretno predmetno vezljivost. V vsakem primeru

${ }^{26}$ Med splošnostjo in oslabljenostjo pomena določenega glagola je zelo tanka meja oz. prehod. V ruskem jezikoslovju je utrjeno ločevanje med predmetnimi in povedkovimi udeleženci, tako da se tudi skladenjskopomenska bližina orodja/sredstva dejanja in načina dejanja razločuje tako, da je orodje/sredstvo dejanja v vlogi predmetnega udeleženca, način dejanja pa označuje t. i. povedkov udeleženec, ki je del povedkovodoločilne vezljivosti (Muravenko 1998: 77). 
gre za kolizijo med predmetom in prislovnim določilom s tem, da ima prednost pomenski vidik pred skladenjskim (Uličný 2000: 20).

Glede na povedano so možne strukturnoskladenjske različice z določili: Piše ročno/strojno (kako?) s peresom/z računalnikom (s čim?) nasproti Piše s peresom/z računalnikom (kako?) nasproti Računa s svinčnikom/z računalnikom (kako? => prim. pog.: Računa peš).

\section{Dopolnjena dosedanja delitev prislovov glede na propozicijskost $\mathbf{v}$ sporočilu oz. povedi}

$\mathrm{Z}$ vidika pomenske podstave oz. propozicije se vrstni prislovi ločujejo:

(1) Propozicijski prislovi ali zunanjeokoliščinski prislovi (izražajo zunanje okoliščine glagolskega dejanja, in sicer kraj in čas, deloma pa zlasti tudi način). S svojim sintagmatskim jedrom tvorijo polavtomatizirane besedne zveze.

(1.1) Istopropozicijski vrstni prislovi (z motivirajočim samostalnikom v podstavi), ki glagolsko dejanje opredeljujejo:

(1) prostorsko/časovno (s podstavo 'v/na kraju/času': laboratorijsko/ ambulantno pregledati, cestno se usmerjati, mesečno poročati);

(1.1) v/kot (< 'biti/nahajati se / obstajati kot': skupinsko delovati ('delovati v skupini'), parno drsati ('drsati v paru'), množično se zbirati ('zbirati se v množici / v množico');

(2) vzročno (s podstavo 'zaradi/od česa/koga': denarno vztrajati/prenesti, telesno/duševno vzdržati)

(3) načinovno

(3.1) sredstveno / snovno (s podstavo 's čim': računalniško obdelati - obdelati z računalnikom, instrumentalno poskusiti, beliti z apnom / s čopičem, bežati v copatih, politično poudariti)

(3.2) spremstvo (s podstavo 's kom': bratsko deliti, prijateljsko popivati)

(3.3) ozirnost (s podstavo 'glede na koga/kaj': biološko prizadeti, slovnično popraviti, prehransko se zanemariti)

(3.4) posledičnost (s podstavo 'do česa': smrtno se ponesrečiti)

(1.2) Neistopropozicijski; pri izglagolskih / deležijskih prislovih gre za "vgraditev ene stavčnopovedne propozicije v drugo« (Vidovič Muha 2000: 76); deležijski prislovi z obrazilom -(o/e)č ali -aje/-é in družljivost s prislovom stopnje ni mogoča (molče spremljati dogajanje, stoje opazovati promet).

(2) Nepropozicijski modifikacijski oz. notranjeokoliščinski lastnostni prislovi (izražajo notranjo lastnost glagolskega dejanja); s svojim sintagmatskim jedrom 
tvorijo aktualizirane besedne zveze/sintagme, ki so besedilne in po govornem dejanju razpadejo.

(2.1) Izpridevniški lastnostni (pomensko družljivi s prislovi stopnje): Dobro piše $>$ Zelo dobro piše) .

(2.2) Izpridevniški vrstni z motivirajočim samostalnikom v podstavi:

(2.2.1) s samostalniki s podkategorijo človeško+: (po) človeško se obnašati, (po) sosedsko pomagati, (po) vojaško pozdraviti, (po) slovensko govoriti ipd.

(2.2.2) s samostalniki v vlogi enakosti/primere: vojaško pozdraviti ('pozdraviti kot vojak'), hekersko delovati ('delovati kot heker').

(3) Z možno propozicijskostjo ali nepropozicijskostjo: v/kot (< propozicijski v 'biti/nahajati se', nepropozicijski kot 'enakost/primera'): 1) propozicijsko: politično/kulturno se udejstvovati ('udejstvovati se v politiki/kulturi'), 2) nepropozicijsko: politično/kulturno se udejstvovati ('udejstvovati se kot politik/ kulturnik'), športno prenesti ('prenesti kot v športu / kot športnik');

(3.1) Samo nepropozicijsko je posamezno drsati (< drsati kot posameznik), medtem ko je v nekaterih drugih primerih odločanje o propozicijskosti odvisno od osebka: On parno/tandemsko drsa (< On drsa v paru / v tandemu) je propozicijska raba nasproti nepropozicijski Onadva parno/ tandemsko drsata (< Onadva drsata kot par < Onadva sta pri drsanju par), kjer je parno/tandemsko rabljeno nepropozicijsko; podobno lahko sklepamo pri prislovu skupinsko, kjer edninska in dvojinska raba osebka omogočata propozicijsko rabo $(<O n(d v a)$ deluje(ta) $v$ skupini $)$, množinska raba osebka pa uvaja nepropozicijsko rabo prislova skupinsko s podstavo Oni delujejo kot skupina / Oni so skupina in tako delujejo ipd.

\section{VIRI IN LITERATURA}

Přemysl ADAMEC, 1978: Složené propozice a jejich syntaktické realizace v ruštině. Slovo a slovesnost XXXIX/3-4, 278-280.

- -, 1968: O otázce uplatnění členů v strukturních popisech jazyka. Otázky slovanské syntaxe II. Brno: Filosofická fakulta University J. E. Purkyně. 111-114.

Jurij Derenikovič APRESJAN, ${ }^{2} 1995$ : Leksičeskaja semantika. Moskva: Vostočnaja literatura RAN.

Jaroslav BAUER, 1968: Konstitutivní a fakultativní prvky větných schémat. Otázky slovanské syntaxe II. Brno: Filosofická fakulta University J. E. Purkyně. 164-165.

Helena BĚLIČOVÁ, 1982: Sémantická struktura věty a kategorie pádu. /Př́íspěvek k porovnávací syntaxi ruské a české jednoduché věty/. Studie a práce lingvistické 17. Praha: Academia. 
Helena BĚLIČOVÁ, Ludmila UHLÍŘOVÁ, 1996: Slovanská větá. Řada lingvistická sv. 3. Praha: Euroslavica.

František DANEŠ, 1968: Sémantická struktura větného vzorce. Otázky slovanské syntaxe II. Brno: Filosofická fakulta University J. E. Purkyně. 45-49.

František DANEŠ idr., 1987: Větné vzorce v češtině. Praha: Academia.

FIDA, http://www.fida.net

Josef FILIPEC, 1985: Lexikologie. Česká lexikologie. Praha: Academia.

Charles J. FILLMORE, 1965: Indirect Object Constructions in English and the Ordering of Transformations. London - The Hague - Paris: Mouton \& CO.

- -, 1968: The Case for Case. Universals in Linguistic Theory. Ur. E. Bach in R. T. Harms. USA.

Miroslav GREPL idr., 1968: Strukturní typy slovanské věty a jejich vývoj. Otázky slovanské syntaxe II. Brno: Filosofická fakulta University J. E. Purkyně.

Miroslav GREPL idr., 1987: Mluvnice češtiny (MČ 3 - Skladba). Praha: Academia.

Miroslav GREPL, Petr KARLÍK idr., 1998: Skladba češtiny. Praha: Votobia.

Viktor Samuilovič HRAKOVSKIJ idr., 1985: Tipologija konstrukcij s predikatnymi aktantami. Leningrad: Nauka.

Milan JELÍNEK, 1968: Funkce a vývoj syntaktických kondenzátorů v slovanských jazycích. Otázky slovanské syntaxe II. Brno: Filosofická fakulta University J. E. Purkyně. 389-395.

Miloslava KNAPPOVÁ, 1973: K otázkám adverbializace. Slovo a slovesnost XXXIV/2, $150-157$.

Jan KOŘENSKÝ, 1984: Konstrukce gramatiky ze sémantické báze. Praha: Academia.

--, 1974: Problémy konstrukce gramatiky jazyka ze sémantické báze. Slovo a slovesnost XXXV/4, 241-255.

Helena KŘÍŽKOVÁ, 1968: Adverbiální determinace slovesná a větný vzorec. Otázky slovanské syntaxe II. Brno: Filosofická fakulta University J. E. Purkyně. 103-109.

Olga KUNST GNAMUŠ, 1981: Pomenska sestava povedi. Ljubljana.

Olga I. MOSKAL'SKAJA, 1973: Problemy semantičeskogo modelirovanija v sintaksise. Voprosy jazykoznanija XXII/6, 33-43.

Roman MRÁZEK, 1968: Dedukce a empirie pri srovnávací typologii slovanské věty. Otázky slovanské syntaxe II. Brno: Filosofická fakulta University J. E. Purkyně. 185-200.

- -, 1976: Problematika tzv. hierarchizace propozice. Slovo a slovesnost XXXVII/2 (Praha: ČAV), 86-96.

Elena V. MURAVENKO, 1998: O slučajah netrivial'nogo sootvetstvija semantičeskih i sintaksičeskih valentnostej glagola. Semiotika i informatika 36 (Moskva: Russkie slovari), 71-81.

Janez OREŠNIK, 1994: Slovenski glagolski vid in univerzalna slovnica. Ljubljana: SAZU. 
- -, 1996: Nauk novejše slovenistike o povedkovem prilastku. Razprave SAZU XV. Ljubljana. 255-267.

Aleksandr Borisovič PEN'KOVSKIJ, 2004: Očerki po russkoj semantike. Moskva: Jazyki slavjanskoj kul'tury.

Predrag PIPER, ${ }^{2}$ 2001: Jezik i prostor. Beograd: Biblioteka XX vek.

Fran RAMOVŠ, 1952: Morfologija slovenskega jezika. Skripta, prirejena po predavanjih prof. dr. Fr. Ramovša v 1. 1947/48, 48/49. Ur. B. Pogorelec, P. Merku in M. Sovre. Ljubljana: DZS.

Zdenka RUSÍNOVÁ, 1972: O adverbializaci předložkových výrazú. Jazykovedný časopis XXIII/2, 182-185.

Petr SGALL, 1968: Větné typy a struktura věty z hlediska funkčního. Otázky slovanské syntaxe II. Brno: Filosofická fakulta University J. E. Purkyně. 167-169.

Petr SGALL idr., 1986a: Úvod do syntaxe a sémantiky (Některé nové směry v teoretické lingvistice). Praha: Academia.

- -, 1986b: The Meaning of the Sentence in Its Semantic and Pragmatic Aspects. Praha: Academia.

Slovar slovenskega knjižnega jezika (SSKJ) I-V, 1970, 1975, 1979, 1985, 1991. Ljubljana: DZS.

Otakar ŠOLTYS, 1986: Ke vztahu predikace a centrace. Slovo a slovesnost XLVII/1, $1-15$.

Natal'ja Jul'jevna ŠVEDOVA, 1964: Determinirujuščij ob"'jekt i determinirujuščeje obstojatel'stvo kak samostajatel'nye rasprostraniteli predloženija. Voprosy jazykoznanija XIII/6, 77-93.

--, 1968: O razgraničenii prostogo predloženija i shodnyh s nim konstrukcij. Otázky slovanské syntaxe II. Brno: Filosofická fakulta University J. E. Purkyně. 65-73.

Jože TOPORIŠIČ, 1982: Nova slovenska skladnja (NSS). Ljubljana: DZS.

- -, ${ }^{4} 2000$ : Slovenska slovnica $(S S)$. Četrta prenovljena in razširjena izdaja. Maribor: Obzorja.

Oldřich ULIČNÝ, 2000: Instrumentál v struktuře české věty. Praha: Universit Karlova v Praze, nakladatelství Karolinum.

Ada VIDOVIČ MUHA, 1984: Nova slovenska skladnja J. Toporišiča. Slavistične revija 32/2. 142-155.

- -, 1988: Slovensko skladenjsko besedotvorje ob primerih zloženk (SSB). Ljubljana: Znanstveni inštitut Filozofske fakultete in Partizanska knjiga.

- -, 2000: Slovensko leksikalno pomenoslovje (SLP). Govorica slovarja. Ljubljana: Znanstveni inštitut Filozofske fakultete.

- -, 2009: Skladenjska interpretacija glagolskih predponskih obrazil - vprašanje propozicije. Slavistična revija 57/2. 251-261.

Viktor V. VINOGRADOV, 1947: Russkij jazyk (grammatičeskoe učenie o slove). Moskva, Leningrad. 


\section{ON PROPOSITION IN ADVERBS IN SLOVENE (FROM ASPECT OF SLAVIC LINGUISTICS)}

We limit our discussion of proposition of adverbs to linguistic (systemic) semantics in the framework of single communication, which generally is a one-clause sentence. From the perspective of communication's finality we may talk about the components/ units of same-proposition as well as (wider) inter-communicative non-same-proposition in comparison to non-propositional components.

In line with the grammatical tradition essential components of proposition form the proposition core, and are defined by verbal valency. They fall under semantic necessity that is tied to valency, and only those participants who have a concrete (denotative and referential) meaning may serve to introduce valency. Thus concrete (denotative) semantics relating to participants expressing manner or instrument (with what and how to create or manage something) is also one of the prerequisites for proposition and, consequently, valency.

From the point of view of proposition, adverbs may be divided into propositional - i.e. same-proposition (time, place and noun-motivated) - and non-same-propositional participial adverbs. Non-propositional adverbs are modification, adjective-derived quality adverbs. Certain noun-derived adverbs, however, allow for propositional and nonpropositional use, depending on the verbal meaning or verbal valency. 